\title{
Effect of Soaking Time and Steeping Temperature on Biochemical Properties and $\gamma$-Aminobutyric Acid (GABA) Content of Germinated Wheat and Barley
}

\author{
Sasathom Singkhomart and Gi-Hyung Ryu ${ }^{\dagger}$ \\ Department of Food Science and Technology, Kongju National University, Chungnam 340-802, Korea
}

\begin{abstract}
The objective of this research was to investigate the effects of soaking time (6, 12 and 24 hr) and steeping temperature $\left(25,30\right.$ and $\left.35^{\circ} \mathrm{C}\right)$ on germination time, germination percentage and weight loss of wheat and barley. Changes in chemical composition (such as protein, fat, and ash), reducing sugar content, enzyme activity and pasting profile and GABA ( $\gamma$-animobutyric acid) content of germinated wheat and barley were also evaluated. The results clearly suggest that the short soaking time and lower steeping temperature significantly decreased germination time and weight loss, while germination percentage increased. Regarding the chemical composition, the protein content of wheat and barley was slightly increased after germination but there was no significant difference in content of crude fat and ash of both germinated cereals. The reducing sugar content of both germinated cereals decreased as the steeping temperature increased from $25^{\circ} \mathrm{C}$ to $35^{\circ} \mathrm{C}$. Increasing soaking time and steeping temperature led to increased amylase activity, and also corresponded to reduced paste viscosity. The highest GABA content that occurred with soaking times of 6 and $12 \mathrm{hr}$ and a steeping temperature of $35^{\circ} \mathrm{C}$ was $1,467.74$ and $1,474.70 \mu \mathrm{g} / \mathrm{g}$ for germinated wheat and $2,108.13$ and $1,691.85 \mu \mathrm{g} / \mathrm{g}$ for germinated barey. This study indicated that the optimum germination process for wheat and barley is a low steeping temperature and a short soaking time.
\end{abstract}

Key words: germination, soaking time, steeping temperature, $\gamma$-animobutyric acid, stirring number

\section{INTRODUCTION}

Germination, the first step of malting process, is the growth of an embryonic plant contained within a seed; it results in the formation of the seedling. Germination needs water to activate the plant hormone. Allowing water to penetrate through and diffuse to the aleurone layers induces enzyme synthesis, thus the grains must be steeped or hydrated until those biochemicals are induced. Germinated cereal is a cereal grain that has been allowed to germinate under controlled conditions to make a limited amount of seedling growth. The quality of the germinated cereals is influenced by the raw material, variety, steeping, germination condition, and chemicals and plant hormones added during steeping (1). Steeping is widely acknowledged as a critical stage in the germination process; it increases the moisture content of wheat and barley grains to promote germination and influences the overall malt quality (2).

During the process of germination, the enzymes produced or activated degrade major components, such as starch, non-starch polysaccharides and proteins, into small molecular compounds, which leads to an increase of oligosaccharides and amino acids in barley (2), wheat
(3), oat (4) and rice (5). A number of studies have documented germination's advantages and health benefits. One of the main enzymes in the germination process, as determined by stirring number or falling number method, is $\alpha$-amylase. Stirring number is a viscometric assay that involves the rapid gelatinization of flour or meal suspension in water by Rapid Visco Analyser (RVA) instrument. This method is universally used to assess $\alpha$ amylase activity and grain quality (6). Many researchers have reported flour obtained from germinated cereals had greater nutritional properties than flours from non-germinated cereals. Germination also stimulates biochemical activities that improve some nutrients, such as certain vitamins, phenolic compounds $(7,8)$, phytic acid, ferulic acid (9) and, especially, $\gamma$-aminobutyric acid (GABA) (10).

GABA is non-protein amino acid compound, and is produced primarily by the decarboxylaton of L-glutamic acid, catalyzed by the enzyme glutamate decarboxylase (GAD) (11). GABA provides beneficial effects for human health by playing a major role in neurotransmission and induction of hypotensive and diuretic effects (12), appearing to regulate anxiety, sleep, the immune system, fat metabolism, accelerating metabolism in brain and 
prevention of headaches or effects of cerebral arteriosclerosis (13). Several processes have been described to improve GABA content in germinated cereals. Chung et al. (14) found GABA content in germinated barley was highest at steeping $5^{\circ} \mathrm{C}$ in $\mathrm{pH} 6$ for $72 \mathrm{hr}$. Komatsuzaki et al. (15) reported that, after soaking water with aeration for $21 \mathrm{hr}$ at $35^{\circ} \mathrm{C}$, GABA content in germinated brown rice was higher than with conventional soaking methods. GABA is found widely in some microorganisms, tea leaves, soybean seedlings and germinated beans and rice, while GABA in the germinated wheat and barley lacks researched data. Thus, germination effects in wheat and barley are of great interest for cereal products. Germinated wheat and barley can be used in baby food, bakery products and the confectionary industry. Germination is an economical processing technology that provides a relatively simple and non-chemical approach to improve bioavailability of nutrients in cereal (14).

The aim of this research was to study the optimum germination conditions in wheat and barley. The effect of different soaking times and steeping temperatures on the biochemical properties and GABA content of germinated wheat and barley was investigated.

\section{MATERIALS AND METHODS}

\section{Materials}

Wheat (Triticum spp.) and barley (Hordeum vulgare L.) were purchased at a local market in South Korea. All grains were cleaned of dust and any other contaminants. The samples were kept in sealed plastic bags in dry and cool rooms until analysis. All chemicals and reagents in this research were of analytical grade.

\section{Germination process}

The wheat and barley (250 g each) were soaked in distilled water at a ratio of $1: 4(\mathrm{w} / \mathrm{v})$ for 6,12 and 24 $\mathrm{hr}$. The water in the container was changed every $3 \mathrm{hr}$ during the soaking period. For germination, the grain was removed and then placed on a tray which was covered with moistened thin cloth. The sample was germinated at 25,30 and $35^{\circ} \mathrm{C}$ with water sprayed 3 times daily. The germinated samples were dried in oven at $50^{\circ} \mathrm{C}$ for $24 \mathrm{hr}$. Then, the samples were ground to pass through a $0.5 \mathrm{~mm}$ screen before analysis. The percentage of germination was also investigated, from which one hundred whole grains were randomly selected and placed in petri dishes, and then the cereals that germinated (with emerging radicle) were counted. The results of triplicate assays were calculated as the percentage of germinated cereals to the total number of cereals tested. Germination time was observed after the radical emerged from the caryopses at length root $0.5 \sim 1 \mathrm{~cm}$

\section{Proximate analysis}

Moisture, crude protein, crude fat, crude ash and carbohydrate were measured by the standard method of the AOAC (16). Determinations were performed in triplicate for each sample.

\section{Determination of reducing sugar content and amylase} activity

The reducing sugar content of both un-germinated and germinated wheat and barley was determined with the colorimetric method using 3,5-dinitrosalicylic acid (DNS) (17). Glucose was used as standard. Amylase activity obtained from stirring number (SN) was measured with RVA (RVA-3D, Newport Scientific Inc., Sydney, Australia), according to the method by Lin et al. (18). A high SN value indicates greater viscosity and thus lower amylase activity. The falling number also correlates with amylase activity in the same fashion, such that the greater the falling number, the greater the viscosity of the sample, indicating reduced amylase activity

\section{Pasting properties}

Un-germinated and germinated wheat and barley samples ( $3.5 \mathrm{~g}, 14 \%$ moisture) placed in canisters were mixed with water $(25 \mathrm{~mL})$, and then heated to $50^{\circ} \mathrm{C}$ for $1 \mathrm{~min}$, raised to $95^{\circ} \mathrm{C}$ in $3.5 \mathrm{~min}$, maintained for $3 \mathrm{~min}$ and cooled to $50^{\circ} \mathrm{C}$ in $3.8 \mathrm{~min}$, and held for $2 \mathrm{~min}$ in a rapid visco-analyzer (RVA-3D, Newport Scientific Inc.). The suspension was stirred at $960 \mathrm{rpm}$ for $1 \mathrm{~min}$ and then at $160 \mathrm{rpm}$ throughout the test. The changes in viscosity were expressed in Rapid Visco Units (RVU). All measurements were performed in triplicate.

\section{Analysis of GABA content}

The GABA content in the germinated wheat and barley was determined according to the method described by Kitaoka and Nakano (19) and Watchararparpaiboon et al. (10). Three grams of ground germinated cereal were extracted with $30 \mathrm{~mL}$ of $70 \%$ ethanol at room temperature and then centrifuged at $7000 \times g\left(4^{\circ} \mathrm{C}\right)$ for 20 min. The supernatant was collected and re-extracted with $800 \mu \mathrm{L}$ of $70 \%$ ethanol. The sample extract was evaporated to dry under vacuum at $40^{\circ} \mathrm{C}$ and then dissolved with $3 \mathrm{~mL}$ of double distilled water. The aliquot solution $(0.1 \mathrm{~mL})$ was mixed with $0.2 \mathrm{~mL}$ of borate buffer $(\mathrm{pH}$ 9.0), $1 \mathrm{~mL}$ of $6 \%$ phenol reagent and $0.4 \mathrm{~mL}$ of sodium hypochlorite in ice bath. The mixture was placed in a boiling water bath for $10 \mathrm{~min}$. The absorbance was measured at $630 \mathrm{~nm}$ after cooling in an ice bath for $5 \mathrm{~min}$. The $\gamma$-aminobutyric acid standard solution in double distilled water was prepared and assayed under the same conditions. 


\section{Statistical analysis}

All the data statistics on a factorial completely randomized design were performed using analysis of variance (ANOVA) in the SAS program (SAS 6.0, SAS Institute Inc., Cary, NC, USA). The significance level was set at $\mathrm{p}<0.05$.

\section{RESULTS AND DISCUSSION}

Effect of germination conditions on germination percentage, germination time and weight loss percentage

The effect of soaking time (6,12 and $24 \mathrm{hr}$ ) and steeping temperature $\left(25,30\right.$ and $\left.35^{\circ} \mathrm{C}\right)$ on the percentage of germination, germination time, and weight loss percentage in germinated wheat and barley are shown in Table 1. At all soaking periods (6,12 and $24 \mathrm{hr}$ ), the germination percentage of wheat at steeping temperature 25 and $30^{\circ} \mathrm{C}$ was higher than $95 \%$, while at $35^{\circ} \mathrm{C}$ was ranged from $73 \sim 78 \%$. Likewise, the germinated barley at 25 and $30^{\circ} \mathrm{C}$ had high germination percentage (more than $90 \%$ ) when compared with that at $35^{\circ} \mathrm{C}$ (less than $2 \%$ ). The soaking times showed no effect on germination percentage in both cereals. Chung et al. (14) reported that the germination percentage of cereal was highly dependent on the steeping temperature, which was impaired at high steeping temperatures. Table 1 also shows that germination time increased with the increasing soaking time and steeping temperature. For wheat, the steeping temperature at $35^{\circ} \mathrm{C}$ required longer germination times than those of the steeping temperature at $25^{\circ} \mathrm{C}$, at $24 \mathrm{hr}$ and over $60 \mathrm{hr}$. The germination of barley at a steeping temperature of $35^{\circ} \mathrm{C}$ was prolonged more than
$96 \mathrm{hr}$. Long soaking time and high steeping temperature resulted in delayed germination and an increase in both growth of mold and bacteria and undesirable odors (20).

The percentage of weight loss in germinated wheat at steeping temperature $25^{\circ} \mathrm{C}$ was $3.02,3.13$ and $3.67 \%$ and at steeping temperature $35^{\circ} \mathrm{C}$ was $7.78,12.68$ and $12.10 \%$ with soaking times of 6,12 and $24 \mathrm{hr}$, respectively. These trends were also observed in germinated barley. An increase in steeping temperature from $25^{\circ} \mathrm{C}$ to $35^{\circ} \mathrm{C}$ resulted in an increase weight loss percentage of germinated barley as from 10.47 to $12.18 \%$ (6 $\mathrm{hr}), 10.08$ to $13.09 \%(12 \mathrm{hr})$ and 16.60 to $19.99 \%$ (24 hr). Capanazana and Buckle (1) suggested that the weight loss during germination was due to leaching of solids during steeping and increased metabolic growth during germination. Further, increase in weight loss may subsequently decrease the level of nutrients in the germinated rice flour. However, in order for the seed to germinate, sufficient moisture must be attained to activate metabolic development of the roots and shoots (21).

Effect of germination conditions on chemical compositions

The content of chemical composition in un-germinated and germinated of both cereals is given in Table 2. The crude protein, ash and carbohydrate of germinated wheat were slightly increased after germination, while content of crude fat was significantly decreased $(\mathrm{p} \leq 0.01)$. This study observed a significant difference in the chemical composition between germinated barley and germinated wheat. In germinated barley, crude ash and crude fat were not significantly different with un-germinated bar-

Table 1. Effect of soaking time and steeping temperature on germination time, germination percentage and weight loss percentage of germinated wheat and barley

\begin{tabular}{|c|c|c|c|c|c|}
\hline & Soaking time (hr) & Steeping temp. $\left({ }^{\circ} \mathrm{C}\right)$ & Germination time (hr) & $\%$ Germination & $\%$ Weight loss \\
\hline \multirow{9}{*}{ Germinated wheat } & 6 & 25 & $24^{\mathrm{c}}$ & $95.5^{\mathrm{a}}$ & $3.02^{\mathrm{c}}$ \\
\hline & & 30 & $24^{\mathrm{c}}$ & $96.3^{\mathrm{a}}$ & $3.39^{c}$ \\
\hline & & 35 & $60^{\mathrm{ab}}$ & $78.0^{\mathrm{b}}$ & $7.78^{\mathrm{b}}$ \\
\hline & 12 & 25 & $36^{\mathrm{bc}}$ & $95.0^{\mathrm{a}}$ & $3.13^{\mathrm{c}}$ \\
\hline & & 30 & $48^{\mathrm{b}}$ & $94.2^{\mathrm{a}}$ & $3.96^{\mathrm{c}}$ \\
\hline & & 35 & $72^{\mathrm{a}}$ & $75.5^{b}$ & $12.67^{\mathrm{a}}$ \\
\hline & 24 & 25 & $36^{\mathrm{bc}}$ & $95.7^{\mathrm{a}}$ & $3.67^{\mathrm{c}}$ \\
\hline & & 30 & $48^{\mathrm{b}}$ & $95.5^{\mathrm{a}}$ & $5.78^{\mathrm{bc}}$ \\
\hline & & 35 & $72^{\mathrm{a}}$ & $73.4^{\mathrm{b}}$ & $12.10^{\mathrm{a}}$ \\
\hline \multirow{9}{*}{ Germinated barley } & 6 & 25 & $24^{\mathrm{d}}$ & $94.3^{\mathrm{a}}$ & $10.47^{\mathrm{d}}$ \\
\hline & & 30 & $36^{\mathrm{cd}}$ & $94.7^{\mathrm{a}}$ & $11.61^{\mathrm{cd}}$ \\
\hline & & 35 & $96^{\mathrm{a}}$ & $1.0^{\mathrm{b}}$ & $12.18^{\mathrm{cd}}$ \\
\hline & 12 & 25 & $24^{\mathrm{d}}$ & $96.0^{\mathrm{a}}$ & $10.08^{\mathrm{d}}$ \\
\hline & & 30 & $36^{\mathrm{cd}}$ & $94.1^{\mathrm{a}}$ & $12.36^{\mathrm{cd}}$ \\
\hline & & 35 & $96^{\mathrm{a}}$ & $1.0^{\mathrm{b}}$ & $13.09^{\mathrm{c}}$ \\
\hline & 24 & 25 & $36^{\mathrm{cd}}$ & $97.2^{\mathrm{a}}$ & $16.60^{\mathrm{b}}$ \\
\hline & & 30 & $48^{\mathrm{b}}$ & $92.0^{\mathrm{a}}$ & $18.11^{\mathrm{a}}$ \\
\hline & & 35 & $96^{\mathrm{a}}$ & $0.0^{\mathrm{b}}$ & $19.99^{\mathrm{a}}$ \\
\hline
\end{tabular}

Means within columns followed by the same letter are not significantly different at $\mathrm{p}<0.05$. 
Table 2. Chemical composition of germinated wheat and barley at different germination conditions

(Unit: \%)

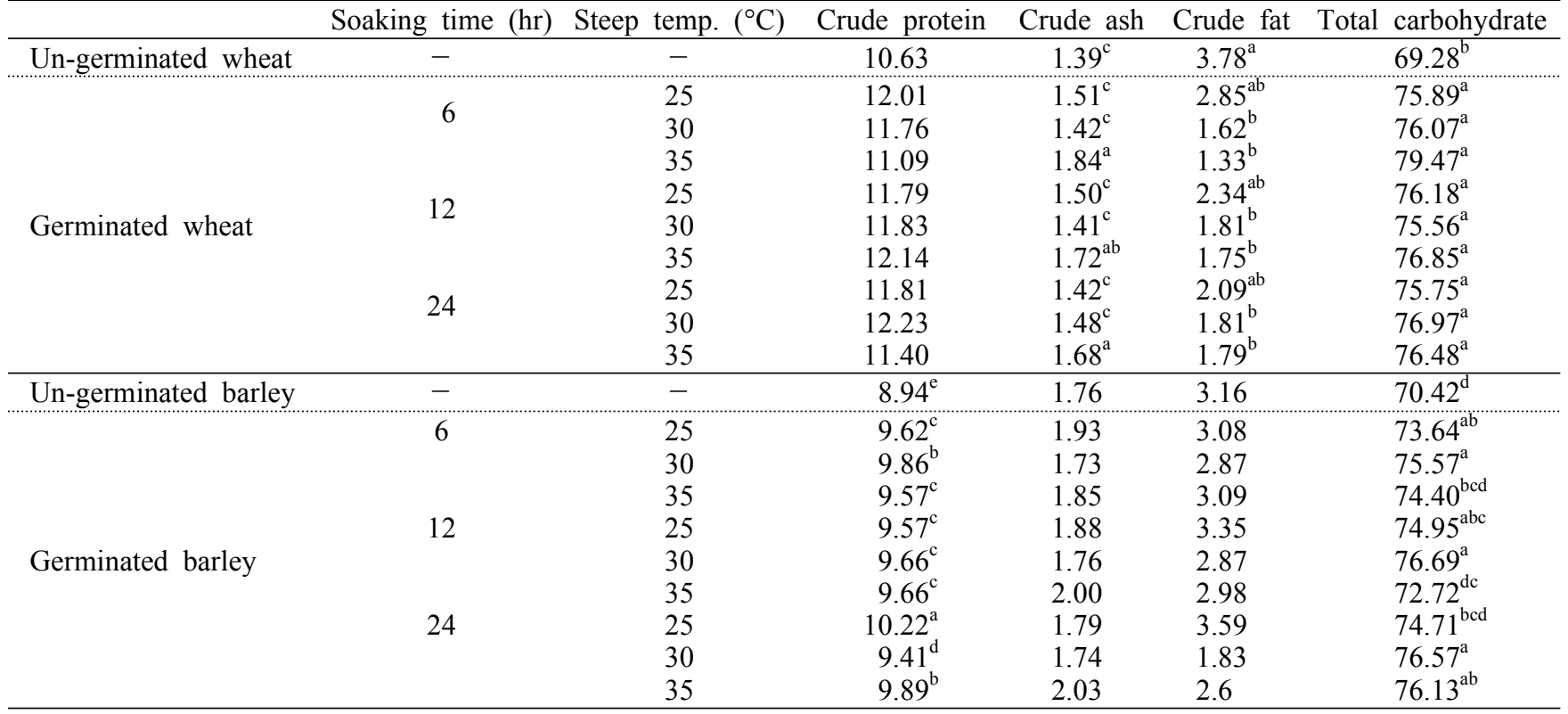

Means within columns followed by the same letter are not significantly different at $\mathrm{p}<0.05$.

ley $(\mathrm{p}>0.05)$, whereas crude protein and total carbohydrate were significantly increased $(p \leq 0.01)$. Similar results were found for germinated brown rice described by Moongngarm and Saetung (21) and Traore et al. (22). Watchararparpaiboon et al. (10) and Tian et al. (23) also reported that crude protein of germinated brown rice and oat was increased after germination. The increase of crude protein after germination is a result of the proteins and amino acids stored in the cereal being decomposed by water absorption, changed into transportable amides, and supplied to the growing parts of the rice seedling (24).

Effect of gemination conditions on the reducing sugar content and amylase activity

Fig. 1 shows that the reducing sugar content of the

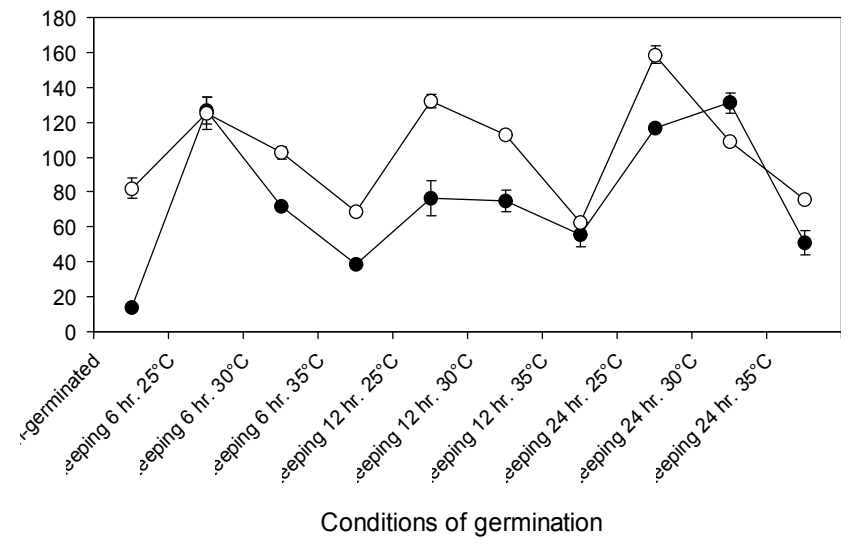

Fig. 1. Reducing sugar content of un-germinated and germinated wheat $(\bullet)$ and barley $(\bigcirc)$ at different soaking time and steeping temperatures. germinated form of both cereals was higher than that of un-germinated cereals. The germinated wheat showed a high content of reducing sugar at a soaking time of $6 \mathrm{hr}$ with a steeping temperature of $25^{\circ} \mathrm{C}(126.74 \mathrm{mg} / \mathrm{g})$ and a soaking time of $24 \mathrm{hr}$ a with steeping temperature of $30^{\circ} \mathrm{C}(130.95 \mathrm{mg} / \mathrm{g})$. The reducing sugar content of germinated barley at steeping temperature $25^{\circ} \mathrm{C}$ was $125.28,132.13$ and $158.75 \mathrm{mg} / \mathrm{g}$ for soaking times of 6, 12 and $24 \mathrm{hr}$. These reducing sugar content levels were higher than those of at steeping temperatures of 30 and $35^{\circ} \mathrm{C}$. Based on our results, we observe that the reducing sugar content in geminated wheat and barley decreased with increasing steeping temperature. However, the reducing sugar content of germinated barley was slightly different at each soaking time. Temperature is one of the main factors affecting germination and could have had an important role in the development of sugars (25).

The changing of amylase activity during germination of wheat and barley was measured using the stirring number method $(\mathrm{SN})$ and the results are presented in Fig. 2. The higher SN values indicate lower amylase activity (26). In the present study, the amylase activity of wheat and barley was increased after germination. The highest amylase activity (lowest SN values) of germinated wheat was found at a steeping temperature of $25^{\circ} \mathrm{C}$, followed by 30 and $35^{\circ} \mathrm{C}$, respectively. In barley, the enzyme activity after germination was higher when it was steeped at $25^{\circ} \mathrm{C}$ than that at 30 and $35^{\circ} \mathrm{C}$. It is well documented that, upon germination, cereals synthesize enzymes whose activity depends upon temperature, moisture, the nature of additives used, genotype and en- 


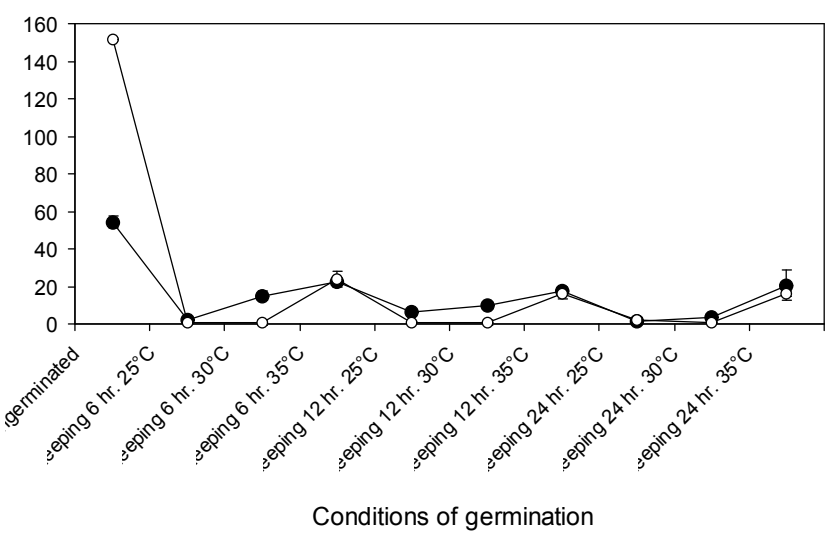

Fig. 2. Stirring number of un-germinated and germinated wheat $(\bullet)$ and barley $(\bigcirc)$ at different soaking times and steeping temperatures.

vironmental conditions (27). Further, the soaking time shows some influence on SN values and/or enzyme activity in germinated barley. Increasing steeping temperature contributes to decrease amylase activity and content of reducing sugar of germinated wheat and barley. The result of reducing sugars from germinated wheat and barley was consistent with result of amylase activity obtained by using the SN method. The increase of reducing sugar content is due to the starch degradation by amylases during germination and the pattern of changes in reducing sugar observed in wheat and barley is similar to that reported for other cereals $(10,28-31)$.

Effect of germination conditions on pasting properties The paste viscosity of wheat and barley during germi- nation is shown in Table 3. The pasting profile of wheat and barley after germination was significantly decreased in values of pasting parameters, including peak viscosity (PV), breakdown (BD), final viscosity (FV) and setback viscosity $(\mathrm{SB})(\mathrm{p} \leq 0.01)$. The pasting temperature of germinated wheat and barley at steeping temperature 25 and $30^{\circ} \mathrm{C}$ was too low, which is similar to the results of Mohan et al. (30) and Manners (32). While, the pasting temperature at $35^{\circ} \mathrm{C}$ with soaking times of 6,12 and $24 \mathrm{hr}$ was $89.4,91.3$ and $88.4^{\circ} \mathrm{C}$ for germinated wheat and $92.6,94.8$ and $61.9^{\circ} \mathrm{C}$ for germinated barley. During germination, the starch is degraded by the enzymes in the seed. Amylases break down the amylose and amylopectin of the starch producing smaller dextrins, maltose and glucose, thus reducing paste viscosity (33). Raschke et al. (34) reported a correlation between pasting profile, falling number and amylase activities in sorghum malt, such that paste viscosity and falling number decreased with rapidly increasing amylase activity.

Effect of germination conditions on the GABA content

The GABA content was determined by spectrophotometer, which is a rapid and simplified method because of its greater convenience and sensitivity (10). The soaking time and steeping temperature significantly affected the content of GABA in germinated wheat and barley (Fig. 3). The GABA contents of raw wheat and barley were 473.46 and $428.49 \mu \mathrm{g} / \mathrm{g}$, respectively, which were significantly lower than wheat and barley after germination. In germinated wheat, the GABA content was the

Table 3. Pasting properties of germinated wheat and barley at different germination conditions

\begin{tabular}{|c|c|c|c|c|c|c|c|}
\hline & $\begin{array}{l}\text { Soaking time } \\
(\mathrm{hr})\end{array}$ & $\begin{array}{c}\text { Steep temp. } \\
\left({ }^{\circ} \mathrm{C}\right)\end{array}$ & $\begin{array}{c}\text { Peak } \\
\text { viscosity }\end{array}$ & $\begin{array}{l}\text { Breakdown } \\
\text { viscosity }\end{array}$ & $\begin{array}{c}\text { Final } \\
\text { viscosity }\end{array}$ & $\begin{array}{c}\text { Setback } \\
\text { viscosity }\end{array}$ & $\begin{array}{l}\text { Pasting } \\
\text { temp. }\left({ }^{\circ} \mathrm{C}\right)\end{array}$ \\
\hline Un-germinated wheat & - & - & $309^{\mathrm{a}}$ & $152^{\mathrm{a}}$ & $583^{\mathrm{a}}$ & $426^{\mathrm{a}}$ & $88.9^{\mathrm{b}}$ \\
\hline Germinated wheat & 24 & $\begin{array}{l}25 \\
30 \\
35 \\
25 \\
30 \\
35 \\
25 \\
30 \\
35\end{array}$ & $\begin{array}{c}9^{\mathrm{e}} \\
46^{\mathrm{ed}} \\
167^{\mathrm{c}} \\
9^{\mathrm{e}} \\
63^{\mathrm{d}} \\
110^{\mathrm{c}} \\
9^{\mathrm{e}} \\
46^{\mathrm{ed}} \\
201^{\mathrm{b}}\end{array}$ & $\begin{array}{c}9^{\text {ef }} \\
40^{\text {cd }} \\
89^{\mathrm{b}} \\
5^{\mathrm{f}} \\
34^{\mathrm{cde}} \\
50^{\mathrm{c}} \\
9^{\mathrm{ef}} \\
14^{\mathrm{def}} \\
54^{\mathrm{c}}\end{array}$ & $\begin{array}{r}4^{\mathrm{c}} \\
22^{\mathrm{c}} \\
397^{\mathrm{b}} \\
4^{\mathrm{c}} \\
68^{\mathrm{c}} \\
295^{\mathrm{b}} \\
11^{\mathrm{c}} \\
75^{\mathrm{c}} \\
558^{\mathrm{a}}\end{array}$ & $\begin{array}{r}3^{\mathrm{d}} \\
16^{\mathrm{d}} \\
317^{\mathrm{bc}} \\
7^{\mathrm{d}} \\
38^{\mathrm{d}} \\
235^{\mathrm{c}} \\
3^{\mathrm{d}} \\
43^{\mathrm{d}} \\
411^{\mathrm{ab}}\end{array}$ & $\begin{array}{l}- \\
- \\
89.4^{\mathrm{b}} \\
- \\
- \\
91.3^{\mathrm{a}} \\
- \\
- \\
88.4^{\mathrm{b}}\end{array}$ \\
\hline Un-germinated barley & - & - & $551^{\mathrm{a}}$ & $170^{\mathrm{a}}$ & $715^{\mathrm{a}}$ & $335^{\mathrm{a}}$ & $69.7^{b}$ \\
\hline Ggerminated barley & 12 & $\begin{array}{l}25 \\
30 \\
35 \\
25 \\
30 \\
35 \\
25 \\
30 \\
35\end{array}$ & $\begin{array}{r}2^{\mathrm{b}} \\
3^{\mathrm{b}} \\
21^{\mathrm{b}} \\
2^{\mathrm{b}} \\
28^{\mathrm{b}} \\
103^{\mathrm{b}} \\
5^{\mathrm{b}} \\
32^{\mathrm{b}} \\
152^{\mathrm{b}}\end{array}$ & $\begin{array}{r}1^{\mathrm{b}} \\
2^{\mathrm{b}} \\
10^{\mathrm{b}} \\
1^{\mathrm{b}} \\
13^{\mathrm{b}} \\
11^{\mathrm{b}} \\
2^{\mathrm{b}} \\
18^{\mathrm{b}} \\
14^{\mathrm{b}}\end{array}$ & $\begin{array}{c}5^{\mathrm{d}} \\
3^{\mathrm{d}} \\
146^{\mathrm{bcd}} \\
7^{\mathrm{d}} \\
76^{\mathrm{cd}} \\
259^{\mathrm{bc}} \\
26^{\mathrm{d}} \\
62^{\mathrm{cd}} \\
334^{\mathrm{b}}\end{array}$ & $\begin{array}{r}3^{\mathrm{d}} \\
5^{\mathrm{d}} \\
135^{\mathrm{bc}} \\
6^{\mathrm{d}} \\
61^{\mathrm{cd}} \\
167^{\mathrm{b}} \\
23^{\mathrm{d}} \\
48^{\mathrm{d}} \\
196^{\mathrm{b}}\end{array}$ & $\begin{array}{l}- \\
- \\
92.6^{\mathrm{a}} \\
- \\
- \\
94.8^{\mathrm{a}} \\
- \\
64^{\mathrm{c}} \\
61.9^{\mathrm{c}}\end{array}$ \\
\hline
\end{tabular}

Means within columns followed by the same letter are not significantly different at $\mathrm{p}<0.05$. 


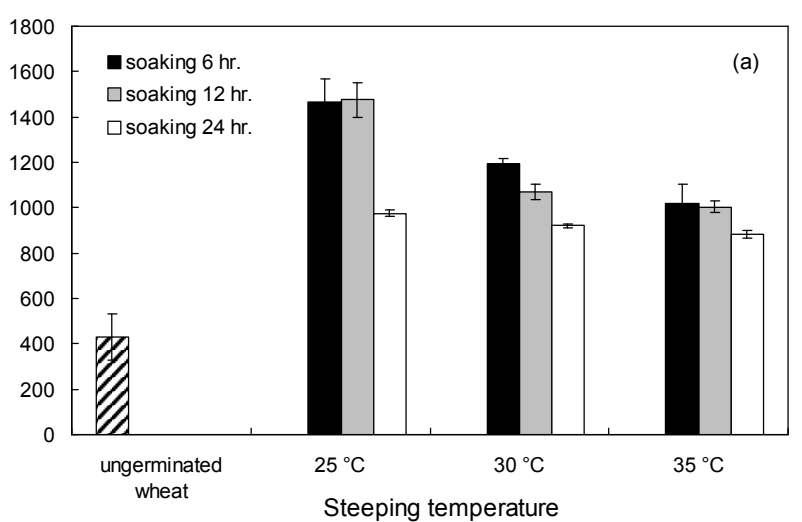

Fig. 3. GABA content of un-germinated and germinated wheat and steeping temperatures 25,30 and $35^{\circ} \mathrm{C}$.

highest, at $1,467.70 \mu \mathrm{g} / \mathrm{g}$, at steeping temperature $25^{\circ} \mathrm{C}$ and soaking time of $6 \mathrm{hr}$. The GABA content at soaking time $24 \mathrm{hr}$ after steeping at 25,30 and $35^{\circ} \mathrm{C}$ was 976.00 , 920.85 and $883.59 \mu \mathrm{g} / \mathrm{g}$, respectively. With germinated barley at a $6 \mathrm{hr}$ soaking time, the GABA content at steeping temperature $25^{\circ} \mathrm{C}(2,108.13 \mu \mathrm{g} / \mathrm{g})$ was increased when compared to the GABA content at steeping $30^{\circ} \mathrm{C}$ $(1028.37 \mu \mathrm{g} / \mathrm{g})$. There were significant differences with the GABA content resulting from steeping at $35^{\circ} \mathrm{C}$ $(712.94 \mu \mathrm{g} / \mathrm{g})$. Our results indicate that GABA content was increased with decreasing soaking time $(\mathrm{p} \leq 0.01)$. Komastuzaki et al. (15) suggest that the GABA content increased by water soaking may be due to the activation of glutamate decarboxylase (GAD), which converts glutamate to GABA. However, it has been reported that the GABA content in germination of barley was also affected by steeping temperature (14). Roberts et al. (35) propose that GABA increases rapidly in plant tissues in response to various forms of stress such as hypoxia. On the other hand, the effects of longer soaking times are decreased GABA content, increased growth of mold and bacteria, and the production of undesirable odors (20).

\section{CONCLUSION}

The soaking time and steeping temperature significantly affected percentage germination, germination time, weight loss of germinated wheat and barley, but changes in chemical composition was not as pronounced. Short soaking time and low steeping temperature significantly influenced the amylase activity and reducing sugar content, which leads to the reduction of viscosity in germinated wheat and barley. Based on our results, optimal conditions for germination were achieved in both wheat and barley with a $6 \mathrm{hr}$ soaking time and $25^{\circ} \mathrm{C}$ steeping temperature. Under these conditions, we observed a higher percentage of germination, enzyme activity and GABA content, and a shorter germination time.

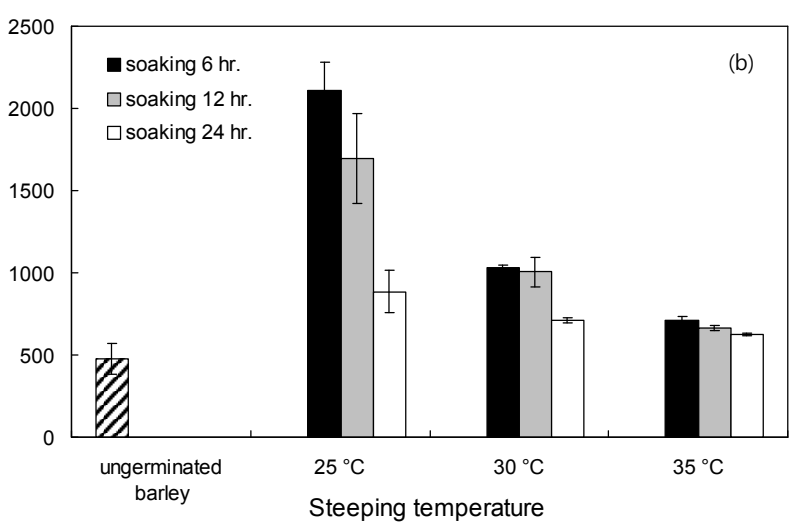
(a) and barley (b) variety at soaking times 6, 12 and $24 \mathrm{hr}$ ACKNOWLEDGEMENTS

This research was supported by Technology Development Program for Agriculture and Forestry, Ministry for Food, Agriculture, Forestry and Fisheries, Republic of Korea.

\section{REFERENCES}

1. Capanazana MV, Buckle KA. 1997. Optimisation of germination conditions by response surface methodology of a high amylase rice (Oryza sativa) cultivar. Ledesm Wiss u Technol 30: 155-163.

2. Rimsten L, Stenberg T, Andersson R, Andersson A, Aman P. 2003. Determination of beta-glucan molecular weight using SEC with alcofluor detection in cereal extracts. Cereal Chem 80: 485-490.

3. Yang F, Basu TK, Ooraikul B. 2001. Studies on germination conditions and antioxidant contents of wheat grain. Int J Food Sci Nut 52: 319-330.

4. Mikola M, Brinck O, Jones BL. 2001. Characterization of oat endoproteinases that hydrolyze oat avenins. Cereal Chem 78: 55-58.

5. Manna KM, Naing KM, Pe H. 1995. Amylase activity of some roots and sprouted cereals and beans. Food Nutr Bull 16: 1-4.

6. Hagberg S. 1961. Simplified method for determining $\alpha-$ amylase activity. Cereal Chem 38: 202-203.

7. Frias J, Miranda ML, Doblado, R, Vidal-Valverde C. 2005. Effect of germination and fermentation on the antioxidant vitamin content and antioxidant capacity of Lupinus albus L. var. Multolupa. Food Chem 92: 211-220.

8. Fernadez-Orozco R, Frias J, Zielinski H, Piskula MK, Kozlowska H, Vidal-Valverde C. 2008. Kinetic study of the antioxidant compounds and antioxidant capacity during germination of Vigna radiata cv. emerald, Glycine max cv. jutro and Glycine max cv. merit. Food Chem 111: 622-630.

9. Tian S, Nakamura K, Kayahara H. 2004. Analysis of phenolic compounds in white rice, brown rice, and germinated brown rice. J Agric Food Chem 52: 4808-4813.

10. Watchararparpaiboon W, Laohakunjit N, Kerdchoechuen O. 2010. An improved process for high quality and nutrition of brown rice production. Int J Food Sci Tech 16: 147-158.

11. Mayer R, Cherry J, Rhodes D. 1990. Effects of heat shock 
on amino acid metabolism of cowpea cells. Plant Physio 94: 796-810.

12. Aurisano N, Bwertani A, Reggiani R. 1995. Anaerobic accumulation of 4-aminobutyrate in rice seedlings: causes and significance. Phytochemistry 38: 1147-1150.

13. Shoichi I. 2004. Marketing of value-added rice products in Japan: germinated brown rice and rice bread. FAO Rice Conference. February 11-12, Rome, Italy. p 1-10.

14. Chung HJ, Jang SH, Cho HY, Lim ST. 2009. Effects of steeping and anaerobic treatment on GABA ( $\gamma$-aminobutyric acid) content in germinated waxy hull-less barley. $J$ Food Sci Technol 42: 1712-1716.

15. Komatsuzaki N, Tsukahara K, Toyoshima H, Suzuki T, Shimizu N, Kimura T. 2007. Effect of soaking and gaseous treatment on GABA content in germinated brown rice. $J$ Food Eng 78: 556-560.

16. AOAC. 1990. Official methods of analysis. 15th ed. Association of Official Analytical Chemists, Washington, DC, USA.

17. Miller GL. 1959. Use of dinitrosalicylic acid reagent for determination of reducing sugar. Anal Chem 31: 426-428.

18. Lin R, Horsley RD, Schwarz PB. 2008. Associations between caryopsis dormancy, $\alpha$-amylase activity, and preharvest sprouting in barley. $J$ Cereal Sci 48: 446-456.

19. Kitaoka S, Nakano Y. 1969. Colorimetric determination of $\omega$-amino acid. $J$ Biochem 66: 87-94.

20. Hoseney CR. 1994. Malting and brewing. In Principles of Cereal Science and Technology. 2nd ed. American Association of Cereal Chemists, St. Paul, MN, USA. p 177181.

21. Moongngarm A, Saetung N. 2010. Comparison of chemical compositions and bioactive compounds of germinated rough rice and brown rice. Food Chem 122: 782-788.

22. Traore T, Mouquet $\mathrm{C}$, Icard-Verniere $\mathrm{C}$, Traore AS, Treche S. 2004. Changes in nutrient composition, phytate and cyanide contents and alpha-amylase activity during cereal malting in small production units in Ouagadougou (Burkina Faso). Food Chem 88: 105-114.

23. Tian B, Xie B, Shi J, Wua J, Cai Y, Xu T, Xue S, Deng Q. 2010. Physicochemical changes of oat seeds during germination. Food Chem 119: 1195-1200.
24. Lea PJ, Robinson SA, Stewart GR. 1990. The biochemistry of plants. Miflin BJ, Lea PJ, eds. Academic Press, London, UK. p 121-159.

25. Aniche NG, Okafor N. 1989. Studies on the effect of germination time and temperature on maliting of rice. $J$ Inst Brew 95: 165-167.

26. Ragaee S, Abdel-Aal EM. 2006. Pasting properties of starch and protein in selected cereals and quality of their food products. Food Chem 95: 9-18.

27. Finney PL. 1983. Effect of germination on cereal and legume nutrient changes and food and feed value: A comprehensive review. In Recent Advances in Phytochemistry. Nozzolillo C, Lean PJ, Loeus FA, eds. Plenum Press, New York, USA. p 229-305.

28. Lorenz K. 1980. Cereal sprouts: composition, nutritive value, food applications. Crit Rev Food Sci Nutr 13: 353385 .

29. Suhasini AW, Muralikrishna G, Malleshi NG. 1997. Free sugars and non-starch polysaccharide content of good and poor malting varieties of wheat and their malts. Food Chem 60: 537-540.

30. Mohan BH, Malleshi NG, Koseki T. 2010. Physico-chemical characteristics and non-starch polysaccharide contents of Indica and Japonica brown rice and their malts. $J$ Food Sci Technol 43: 784-791.

31. Helland MH, Wicklund T, Narvhus JA. 2002. Effect of germination time on alpha-amylase production and viscosity of maize porridge. Food Res Int 35: 315-321.

32. Manners DJ. 1985. Some aspects of the structure of starch. Cereals Foods World 30: 462-467.

33. Bewley JD, Black M. 1985. Seeds: Physiology of Development and Germination. Plenum Press, London, UK. p 1367.

34. Raschke AM, Taylor J, Taylor JRN. 1995. Use of falling number and rapid viscosity analyser instruments to estimate sorghum malt diastatic power. J Cereal Sci 21: 97102.

35. Roberts JKM, Callis J, Wemmer D, Walbot V, Jardetzky O. 1984. Mechanism of cytoplasmic $\mathrm{pH}$ regulation in hypoxic maize root tips and its role in survival under hypoxia. Proc Natl Acad Sci USA 81: 3379-3383.

(Received December 13, 2010; Accepted February 24, 2011) 